\title{
STAKEHOLDERS' PERSPECTIVES ON THE SUCCESS CRITERIA FOR PUBLIC-PRIVATE PARTNERSHIP PROJECTS
}

\author{
Robert OSEI-KYEI ${ }^{1, *}$, Albert P. C. $\mathrm{CHAN}^{1}$ \\ ${ }^{1}$ Department of Building and Real Estate, The Hong Kong Polytechnic University, Hung Hom, Hong Kong, China
}

Received 4 May 2016; accepted 2 February 2017

\begin{abstract}
Given the complexity and wide stakeholder interests in public-private partnership (PPP) projects, different parties have different expectations and definitions of PPP project success. This paper explores the perceptual differences on the success criteria for PPP projects among PPP stakeholders. A questionnaire survey was conducted with targeted international PPP experts from the academic, public and private sectors. The research findings show that each stakeholder group considers effective risk management as the most critical success criterion. Moreover, the public and private sectors consider meeting output specifications as the second most critical criteria, whereas the academic sector considers satisfying the need for public facility/service. Further analysis using non parametric tests shows significant differences on the ranking of the criterion, "satisfying the need for public facility/service" between the public and private sectors and between academic and private sectors. These research outputs provide significant insights into how PPP projects' success is evaluated by various PPP stakeholders.
\end{abstract}

Keywords: public-private partnership, success criteria, stakeholders, project success, perspectives.

\section{Introduction}

The prime goal of parties in any construction project is to achieve success (A. P. C. Chan \& A. P. L. Chan, 2004; Turner, Huemann, Anbari, \& Bredillet, 2010). This is more critical in public-private partnership (PPP) project implementation because a country with more successful PPP projects signifies a strong private investment environment of the host country. More importantly, it demonstrates the host country public sector's competency in engaging successful investment partnership with private investors or developers. Thus, achieving PPP projects success has many positive repercussions on the reputation of a country and its public institutions.

Considering that PPP projects success is very critical to practitioners, over the last couple of decades, many research studies have explored the appropriate measures required to achieve PPP projects success (i.e. critical success factors) (Akintoye, Hardcastle, Beck, Chinyio, \& Asenova, 2003; Li, Akintoye, Edwards, \& Hardcastle, 2005a; Osei-Kyei \& Chan, 2015a; Ke, Wang, Chan, \& Lam, 2010). However, very few studies, if any, have examined the criteria required to assess the success of PPP projects. In this regard, from a thorough review of relevant literature, Osei-Kyei, Chan, Javed, and Ameyaw (2017) derived a concise set of fifteen success criteria for PPP projects and examined the overall perceptions of practitioners and implementers. Though, the outputs of Osei-Kyei et al. (2017) considerably inform practitioners and researchers of the success criteria that are considered very critical by all stakeholders and are useful for practice; apparently, different groups of PPP stakeholders have different expectations in PPP arrangements (Mladenovic, Vajdic, Wundsch, \& Temeljotov-Salaj, 2013; Yuan, Skibniewski, Li, \& Zheng, 2010). More essentially, success means different things to different people (Toor \& Ogunlana, 2010; Turner et al., 2010; Davis, 2014, 2016). Therefore, it will be of great benefit for practitioners and implementers to gain in-depth insights into how PPP project success is evaluated by the various groups of stakeholders in PPP projects (Davis, 2016). This would promote better cooperation and integration of ideas when implementing successful PPP projects. Also, project participants will have an overview of the expectations of each project party when implementing PPP projects.

Against this backdrop, the current paper explores our understanding of different perceptions of different stakeholders (i.e. public, private and academic sectors) on the success criteria for PPP projects. Essentially, during the

*Corresponding author. E-mail: oseikyeirobert@yahoo.com 
last couple of decades, the key groups of stakeholders in PPPs are reported to be the public (i.e. government agencies/institutions and metropolitan/district/municipal assemblies) and private sectors (i.e. financiers, contractors, suppliers and consultants) (Tiong, 1996; Ismail \& Azzahra, 2014; Li et al., 2005a; Osei-Kyei, Dansoh, \& Ofori-Kuragu, 2014). However, this study also consiers the academia (researchers) as a relevant group of stakeholder in PPP project implementation (Zhang, 2004, 2005; Ameyaw \& Chan, 2015a; Chan, Yeung, Calvin, Wang, \& Ke, 2011; $\mathrm{Xu}$, Chan, \& Yeung, 2010; Zou, Kumaraswamy, Chung, \& Wong, 2014). This is because the research group provides meaningful suggestions and policy directions to the key decision making parties (public and private sectors) drawing on both their academic and industrial experiences (Yuan et al., 2010). More importantly, researchers offer an objective view of PPP practice and its way forward without taking sides on either the public or private sectors (Chan et al., 2011). Hence, it is equally important for researchers' views to be considered when deciding on the success measures of PPP projects.

The findings of this study are impactful because they highlight and offer new insights into the key success criteria considered by the various groups of stakeholders in PPP projects. Essentially, this will enhance the cooperation and relationship among stakeholders when implementing PPP projects.

\section{Review of stakeholders' perceptions on project success criteria}

Generally, there exist no standardized criteria for measuring construction project success (A. P. C. Chan \& A. P. L. Chan, 2004; Turner et al., 2010) but traditionally, project success is assessed based on time, cost and quality (Atkinson, 1999; Cheung, Tam, Ndekugri, \& Harris, 2000; Lim \& Mohamed, 1999). This is because these set of project success criteria are objective and easy to measure (Cserháti \& Szabó, 2014). Notwithstanding, different project parties have different expectations in projects; hence different perceptions on what constitute success (Davis, 2014, 2016).

Focusing on the traditionally procured projects, quite a number of research studies have identified the criteria for defining success from different stakeholders' perspectives. For example, Lai and Lam (2010) studied the differences in perceptions on nine success criteria among project clients, main contractors and consultants. They found that the three groups of stakeholders put different emphasis on effectiveness, no claims or contractual disputes, job satisfaction, safety and generation of innovative ideas. In addition, the project clients consider profit and time criteria more than the main contractors.

Bryde and Robinson (2005) also by means of a questionnaire survey on contractors and client organization found out that project clients consider satisfying the needs of stakeholders, whereas the contractors put more emphasis on minimizing project cost and duration (time). From the project clients' perspective, Frodell, Josephson, and
Lindahl (2008) identified keeping within budget, finishing on time, quality, and profitability as their key success criteria for projects. Ellatar (2009) also strongly opined that success means different things to different people; hence the project clients consider functionality, time, budget, quality and return on investments whereas the designer put emphasis on clients' satisfaction, quality architectural product, met design fee and project goal and professional staff fulfilment. For contractors, they indicated that meeting schedule, profit, budget and meeting quality specifications are some key success measures that they take into consideration.

Toor and Ogunlana (2010) found out that efficient use of resources is considered highly by project clients and project management consultants, whereas safety is a major concern for design consultants and construction contractors. Further, they highlighted that construction supervision consultants put more emphasis on meeting specifications.

Lastly, Wang, and Huang (2006) from the perspective of construction supervising engineers in China found out that stakeholder relationship, time, cost and quality are their critical success criteria for construction projects.

In PPP project management, few studies have discussed very closely on the success measures for PPP projects from different stakeholders' perspectives. Yuan, Zeng, Skibniewski, and Li (2009) by means of a questionnaire survey examined the perception of PPP stakeholders (i.e. public, private, academic and user) on the performance objectives of PPP projects. They found out that acceptable quality of public project is considered highly important by the four groups of stakeholders. Further, the academic and general public consider quality public service more important than the industrial practitioners (i.e. public and private sectors). Overall, their findings significantly attest to the fact that different PPP stakeholders have different expectations and objectives in PPP project arrangement.

Similarly, Mladenovic et al. (2013) introduced a twolayer approach for assessing the performance of PPP projects. They indicated that the first layer should focus on the achievement of each group of stakeholder's ultimate objectives. They pointed out that the public sector's objectives include effectiveness and value for money, whereas the private sector's objectives include profitability and customer satisfaction. Further, the users' objectives include level of services and environmental impact.

Also, findings from Dixon, Pottinger, and Jordan (2005) reinforce claims by other researchers that different stakeholders have different expectations; hence different stakeholders judge project success differently. Specifically, Dixon et al. (2005) through semi-structured interviews found that in PPP project arrangement, the project advisors put emphasis on efficient and cost-effective procurement process, financiers consider reaching financial close, private investors consider certainty of income, the procuring authority consider the traditional success measures (i.e. time, budget and specifications) and the project sponsor put emphasis on end-users feedback. 
The brief review of related literature demonstrates that there is a need for a holistic evaluation of the perceptions of various PPP stakeholders on the success measures for PPP projects. In this regard, this paper aims to bridge this knowledge gap and provide in-depth insights into how PPP projects success is judged by the various key stakeholders.

\section{Research method}

\subsection{Identification of PPP projects success criteria}

As part of a broader research project that aims to develop a best practice framework for PPP implementation in
Ghana drawing on international experiences; Osei-Kyei et al. (2017) derived a set of 15 PPP projects success criteria from a comprehensive literature review. The set of PPP projects success criteria have been pretested to ascertain their clarity and adequacy. Table 1 shows the set of 15 PPP projects success criteria developed by Osei-Kyei et al. (2017).

\subsection{Selection of respondents}

As this study required an in-depth knowledge in PPP project implementation, a purposive sampling method with pre-defined selection criteria was adopted (Osei-Kyei \&

Table 1. PPP projects success criteria (Osei-Kyei et al., 2017)

\begin{tabular}{|c|c|c|c|c|c|c|c|c|c|c|c|c|c|c|}
\hline \multirow{2}{*}{ Success criteria } & \multirow{2}{*}{ Descriptions } & \multicolumn{13}{|c|}{ Publications } \\
\hline & & 1 & 2 & 3 & 4 & 5 & 6 & 7 & 8 & 9 & 10 & 11 & 12 & 13 \\
\hline Profitability & $\begin{array}{l}\text { A continuous income/ profit is received by } \\
\text { parties during project operation }\end{array}$ & & $\mathrm{X}$ & & & & & & & & & $\mathrm{X}$ & & \\
\hline $\begin{array}{l}\text { Long-term relationship and } \\
\text { partnership }\end{array}$ & $\begin{array}{l}\text { Cordial relationship and well established } \\
\text { coordination are instituted among } \\
\text { stakeholders }\end{array}$ & & & & & & & & & & & & & $\mathrm{X}$ \\
\hline $\begin{array}{l}\text { Satisfying the need for public } \\
\text { facility/service }\end{array}$ & $\begin{array}{l}\text { An implemented PPP project satisfies fully } \\
\text { the need for a public facility/service }\end{array}$ & & & & & & & & & & & & $\mathrm{X}$ & $\mathrm{X}$ \\
\hline Adherence to time & $\begin{array}{l}\text { Project is constructed on/before time } \\
\text { schedule for commissioning }\end{array}$ & & & & & & & & $\mathrm{X}$ & & & & & \\
\hline Adherence to budget & $\begin{array}{l}\text { Project is constructed according to the } \\
\text { estimated cost and it is without any } \\
\text { operational cost overruns }\end{array}$ & & & & & $\mathrm{X}$ & & & $\mathrm{X}$ & $\mathrm{X}$ & & & & \\
\hline $\begin{array}{l}\text { Reduced litigations and } \\
\text { disputes }\end{array}$ & $\begin{array}{l}\text { Contract litigations and disputes are } \\
\text { minimized throughout the project lifecycle }\end{array}$ & & $\mathrm{X}$ & & $\mathrm{X}$ & & & & & & & & & \\
\hline $\begin{array}{l}\text { Reduced public administrative } \\
\text { cost }\end{array}$ & $\begin{array}{l}\text { Lower cost is incurred by the public sector } \\
\text { in the administration of the project because } \\
\text { major project risks are allocated to the private } \\
\text { sector }\end{array}$ & & & & & & & $\mathrm{X}$ & & & $\mathrm{X}$ & & & $\mathrm{X}$ \\
\hline $\begin{array}{l}\text { Effective technology transfer } \\
\text { and innovation }\end{array}$ & $\begin{array}{l}\text { Technical knowledge and innovation are } \\
\text { effectively shared among stakeholders } \\
\text { particularly with local practitioners }\end{array}$ & & & & & & & & & & & $\mathrm{X}$ & & \\
\hline Local economic development & $\begin{array}{l}\text { Project contributes to the economic } \\
\text { development of the community within which } \\
\text { the project is developed }\end{array}$ & & & & $\mathrm{X}$ & & & & & & & & & \\
\hline Environmental performance & $\begin{array}{l}\text { Project does not affect the health and safety } \\
\text { of occupants or the environment }\end{array}$ & & & & $\mathrm{X}$ & & $\mathrm{X}$ & $\mathrm{X}$ & & & & & & \\
\hline Reduced project life cycle cost & $\begin{array}{l}\text { Lower life cycle cost is realised, which } \\
\text { enhances the project's value for money }\end{array}$ & & & & & & & & & & & & & $\mathrm{X}$ \\
\hline $\begin{array}{l}\text { Reliable and quality service } \\
\text { operations }\end{array}$ & $\begin{array}{l}\text { Continuous and uninterrupted project } \\
\text { services are provided and according to the } \\
\text { satisfaction of users }\end{array}$ & & & $\mathrm{X}$ & & & & & $\mathrm{X}$ & & & & & \\
\hline Meeting output specifications & $\begin{array}{l}\text { Project meets the expected output standards/ } \\
\text { requirements and delivery }\end{array}$ & $\mathrm{X}$ & & & & & & & $\mathrm{X}$ & $\mathrm{X}$ & & & & \\
\hline Effective risk management & $\begin{array}{l}\text { Risks are properly identified. The risk sharing } \\
\text { and transfer mechanism are agreed and } \\
\text { effectively implemented by the public and } \\
\text { private parties }\end{array}$ & & & & & & & & & & $\mathrm{X}$ & & $\mathrm{X}$ & \\
\hline $\begin{array}{l}\text { Reduced public and political } \\
\text { protests }\end{array}$ & $\begin{array}{l}\text { The reduction of agitations and protests } \\
\text { which often arise due to increases in tariffs, } \\
\text { lack of transparency, corruption etc. }\end{array}$ & & & & & & & $\mathrm{X}$ & & & & & & \\
\hline
\end{tabular}

1 = Lam and Javed (2015), 2 = A. P. C. Chan and A. P. L. Chan (2004), $3=$ Meng, Zhao, and Shen (2011), 4 = Zhang (2006a), $5=$ Cheung et al. (2000), 6 = Chan, Scott, and Lam (2002), 7 = Zhang (2006b), 8 = Dixon et al. (2005), 9 = Liyanage and Villalba-Romero (2015), $10=\mathrm{Li}$, Akintoye, Edwards, and Hardcastle (2005b), 11 = Mladenovic et al. (2013), 12 = Liu, Love, Davis, Smith, and Regan (2015), 13 = Yuan et al. (2009). 
Chan, 2017). The selection criteria were that the respondent should have an extensive working and/or research experience in PPP project delivery. Also, the respondent should have an in-depth knowledge of PPP project success (Osei-Kyei \& Chan, 2017). Respondents who satisfy these criteria were considered appropriate to offer enough information and knowledge on the success criteria for PPP projects.

\subsection{Questionnaire survey}

An international questionnaire survey was adopted for this study and it is a widely used research method in PPP studies to gather data and measure practitioners' opinion on a phenomenon (Osei-Kyei \& Chan, 2015a; Spector, 1994). In the questionnaire, experts were asked to rate the importance of each success criterion on a 7-point Likert scale (Osei-Kyei et al., 2017). The scale point adopted was considered appropriate as it increases the reliability and provides meaningful interpretation of results (Garland, 1991). In total, 310 PPP experts were sourced and identified from international development banks (including Asia Development Bank, Public-Private Infrastructure Advisory Facility (PPIAF), International Finance Corporation (IFC)), dedicated public and private institutions (including Canadian Council for PPP (CCPPP), Partnerships U.K, Partnerships Victoria) and publications on PPPs in peer reviewed academic journals, conferences and books (Osei-Kyei et al., 2017).
Questionnaires were sent to targeted experts through emails with an option of answering through the "Survey Monkey" online questionnaire platform. This flexibility aimed to increase the number of responses to be received. A period of four weeks was given to respondents and after sending series of reminders within the period, 45 responses were received (Osei-Kyei \& Chan, 2017). Three responses were found to be incomplete and therefore discarded, remaining 42 valid responses for further analysis. Though the recorded response rate of approximately $14 \%$ is low, the sample size of 42 is considered satisfactory for further analysis when compared with previous related studies in PPP procurement (e.g. Zhang, 2004, 2006a (46); Osei-Kyei \& Chan, 2017). However, despite the methodological limitations of small number of responses, small samples are not rare in an international e-mail/web-survey based research in PPPs (e.g. see Salman, Skibniewski, \& Basha, 2007 (15 out of 188 for first survey; 12 out of 128 for second survey); Sachs, Tiong, \& Wang, 2007 (29 responses); Ameyaw \& Chan, 2015a (35 responses out of 326); Osei-Kyei \& Chan, 2017). Further, it should be noted that this study only sought to highlight the key success criteria for PPP projects as perceived by the various groups of stakeholders in PPP projects, therefore the sample size is adequate for further analysis. Tables 2, 3 and 4 present the response rates for each respondent group, experts' years of PPP experience and cultural backgrounds respectively (Osei-Kyei \& Chan, 2017).

Table 2. Response rates for each group of stakeholder (Osei-Kyei \& Chan, 2017)

\begin{tabular}{|c|l|c|c|c|}
\hline \multirow{2}{*}{ Demographic variable } & \multicolumn{1}{|c|}{ Category } & $\begin{array}{c}\text { No. of questionnaires } \\
\text { sent }\end{array}$ & No. of responses & Percentage (\%) \\
\hline \multirow{3}{*}{ Type of sector } & Academia & 84 & 18 & 21.43 \\
\cline { 2 - 5 } & Private & 104 & 11 & 10.58 \\
\cline { 2 - 5 } & Public & 122 & 13 & 10.66 \\
\cline { 2 - 5 } & Total & 310 & 42 & 13.55 \\
\hline
\end{tabular}

Table 3. Experts' working/research experience in PPPs (Osei-Kyei \& Chan, 2017)

\begin{tabular}{|c|c|c|c|c|c|c|}
\hline \multirow{2}{*}{ Years } & \multicolumn{2}{|c|}{ Academic } & \multicolumn{2}{|c|}{ Private } & \multicolumn{2}{|c|}{ Public } \\
\hline & $\mathrm{N}$ & Percentage (\%) & $\mathrm{N}$ & Percentage (\%) & $\mathrm{N}$ & Percentage (\%) \\
\hline Below 6 years & 3 & 16.70 & 2 & 18.18 & 1 & 7.70 \\
\hline $6-10$ years & 5 & 27.80 & 1 & 9.09 & 5 & 38.50 \\
\hline $11-15$ years & 9 & 50.00 & 0 & 0.00 & 4 & 30.70 \\
\hline $16-20$ years & 1 & 5.50 & 1 & 9.09 & 2 & 15.40 \\
\hline 21 years and above & 0 & 0.00 & 7 & 63.64 & 1 & 7.70 \\
\hline Total & 18 & 100 & 11 & 100 & 13 & 100 \\
\hline
\end{tabular}


Table 4. Countries of experts (Osei-Kyei \& Chan, 2017)

\begin{tabular}{|c|c|c|c|}
\hline Region & Countries & No. of experts & $\begin{array}{c}\text { Percentage } \\
(\%)\end{array}$ \\
\hline \multirow[t]{4}{*}{ America } & USA & 2 & 4.76 \\
\hline & Canada & 3 & 7.14 \\
\hline & Brazil & 1 & 2.38 \\
\hline & Sub-total & 6 & 14.28 \\
\hline \multirow[t]{6}{*}{ Asia } & Bangladesh & 1 & 2.38 \\
\hline & China & 1 & 2.38 \\
\hline & Australia & 13 & 30.95 \\
\hline & Indonesia & 1 & 2.38 \\
\hline & Hong Kong & 1 & 2.38 \\
\hline & Sub-total & 17 & 40.47 \\
\hline \multirow[t]{4}{*}{ Africa } & South Africa & 1 & 2.38 \\
\hline & Kenya & 1 & 2.38 \\
\hline & Nigeria & 2 & 4.76 \\
\hline & Sub-total & 4 & 9.52 \\
\hline \multirow[t]{8}{*}{ Europe } & Portugal & 2 & 4.76 \\
\hline & UK & 5 & 11.9 \\
\hline & Switzerland & 1 & 2.38 \\
\hline & Netherlands & 1 & 2.38 \\
\hline & France & 3 & 7.14 \\
\hline & Spain & 2 & 4.76 \\
\hline & Greece & 1 & 2.38 \\
\hline & Sub-total & 15 & 35.7 \\
\hline \multicolumn{2}{|l|}{ Total } & 42 & 100 \\
\hline
\end{tabular}

\subsection{Tools for data analysis}

The Statistical Package for Social Sciences (SPSS) 21.0 was used to conduct statistical analysis including Kendall's Concordance, mean score ranking, non-parametric tests (Kruskall Wallis and Mann Whitney U statistics). First, the Kendall's concordance analysis was conducted to test the degree of consistency among experts in each group of stakeholder. Second, the mean score analysis was performed to establish the relative importance of each PPP projects success criterion as perceived by the public, private and academic sectors. Further, the mean values of PPP projects success criteria were grouped into quartiles for each group of stakeholder.

Lastly to examine the significant differences in the perceptions of the public, private and academic sectors on the rankings of the success criteria, non-parametric tests (i.e. Kruskal-Wallis and Mann Whitney U tests) were performed. The non-parametric tests are very important because the three groups of stakeholders play different roles and have different objectives in PPP project implementation, hence it is anticipated that the importance of some success criteria may receive significant diverse views from the stakeholders.

\section{Results and discussion}

\subsection{Consistency and agreement of responses by experts in each stakeholder group}

The Kendall's concordance analysis was performed for each group of stakeholder at a significance level of 0.05 . The test was conducted with the null hypothesis that "there is no consistency or agreement on rankings given by experts". The computed Kendall's concordance (W) is $0.296,0.414$ and 0.287 for the academic, private and public sectors respectively. Each group of stakeholder had a significance test value of 0.00 , which is below 0.05 . This required the null hypothesis to be rejected for each group, suggesting that there is significant agreement and consistency on the rankings given by experts. This again reaffirms the genuineness and validity of the survey responses furnished by experts in each group of stakeholder.

\subsection{Mean ranking and Quartile groupings of the success criteria for PPP projects as perceived by the public, private and academic sectors}

The mean scores and rankings for each group of stakeholder are presented in Table 5. It is noticeable that the mean values furnished by experts from the public, private and academic sectors range between 4.77 and $6.23,4.45$ and $6.27,4.50$ and 6.28 respectively. The total variations in responses are 1.46, 1.82 and 1.78 for the public, private and academic sectors respectively. This suggests that the public sector rated the set of success criteria more similarly than the experts from the private sector organizations and academic institutions. Nonetheless, the high ratings (i.e. mean values $\geq 4.5$ ) from the three groups of stakeholders indicate the importance of the set of success criteria.

Table 6 presents the quartile groupings (i.e. upper and lower quartiles) of the set of success criteria according to each stakeholder group. The upper quartile contains the $25 \%$ highest mean values of PPP projects success criteria whereas the lower quartile consists of the $25 \%$ lowest mean values of PPP projects success criteria. The upper quartile cut-off values (i.e. hinges) for the public, private and academic sectors are 5.92, 5.55 and 5.72 respectively. Similarly, the lower quartile cut-off values for each group of stakeholder are 5.08 (public), 5.00 (private) and 4.94 (academic).

In the upper quartile subset of each stakeholder group, effective risk management has the highest mean score. This criterion has mean values of $6.23,6.27$ and 6.28 for the public, private and academic sectors respectively. Essentially, the criterion ranked first among each stakeholder group's rankings (see Table 5). This is a clear indication of the significance of proper risk allocation and transfer in PPP arrangements (Ke, Wang, Chan, \& Lam, 2010). Basically, risk sharing and transfer is a unique feature of PPP projects (Akintoye et al., 2003). There are PPP projects which have failed to live up to expectations primarily because of the misallocation and incomplete transfer of risks 
Table 5. Mean scores and rankings of the success criteria for PPP projects by public, private and academic sectors

\begin{tabular}{|c|c|c|c|c|c|c|c|c|c|}
\hline \multirow[b]{2}{*}{ Success criteria } & \multicolumn{3}{|c|}{ Public } & \multicolumn{3}{|c|}{ Private } & \multicolumn{3}{|c|}{ Academic } \\
\hline & Mean & $\begin{array}{l}\text { Standard } \\
\text { deviation }\end{array}$ & Rank & Mean & $\begin{array}{l}\text { Standard } \\
\text { deviation }\end{array}$ & Rank & Mean & $\begin{array}{l}\text { Standard } \\
\text { deviation }\end{array}$ & Rank \\
\hline Reduced public administrative cost & 5.31 & 0.85 & 9 & 5.09 & 0.54 & 9 & 5.17 & 0.79 & 11 \\
\hline Reduced public and political protests & 5.00 & 1.15 & 14 & 4.45 & 0.69 & 15 & 4.61 & 0.50 & 14 \\
\hline Reduced litigations and disputes & 5.31 & 0.85 & 10 & 5.09 & 0.70 & 11 & 5.33 & 0.69 & 8 \\
\hline Satisfying the need for public facility/service & 6.00 & 0.82 & 3 & 4.91 & 0.83 & 14 & 5.78 & 0.73 & 2 \\
\hline Reliable and quality service operations & 5.77 & 0.44 & 5 & 5.82 & 0.40 & 3 & 5.78 & 0.88 & 3 \\
\hline Effective risk management & 6.23 & 0.83 & 1 & 6.27 & 0.65 & 1 & 6.28 & 0.75 & 1 \\
\hline Effective technology transfer and innovation & 5.08 & 0.86 & 11 & 5.00 & 0.89 & 13 & 4.94 & 1.16 & 12 \\
\hline Adherence to time & 5.92 & 0.86 & 4 & 5.55 & 0.69 & 4 & 5.56 & 0.92 & 6 \\
\hline Local economic development & 5.08 & 1.04 & 12 & 5.09 & 0.70 & 10 & 4.83 & 1.10 & 13 \\
\hline Profitability & 5.69 & 0.48 & 7 & 5.18 & 0.87 & 8 & 5.72 & 1.02 & 5 \\
\hline Meeting output specifications & 6.00 & 0.58 & 2 & 6.09 & 0.94 & 2 & 5.72 & 0.89 & 4 \\
\hline Adherence to budget & 5.46 & 0.78 & 8 & 5.45 & 0.82 & 5 & 5.28 & 0.83 & 10 \\
\hline Environmental performance & 4.77 & 0.83 & 15 & 5.00 & 0.63 & 12 & 5.33 & 0.91 & 9 \\
\hline Long-term relationship and partnership & 5.77 & 0.73 & 6 & 5.36 & 0.67 & 6 & 5.50 & 0.62 & 7 \\
\hline Reduced project life cycle cost & 5.00 & 0.71 & 13 & 5.36 & 0.67 & 7 & 4.50 & 1.25 & 15 \\
\hline
\end{tabular}

Table 6. Quartile groupings of PPP projects success criteria from stakeholders' perspectives

\begin{tabular}{|c|c|c|c|c|c|c|}
\hline \multirow{2}{*}{ Quartiles } & \multicolumn{2}{|l|}{ Public } & \multicolumn{2}{|l|}{ Private } & \multicolumn{2}{|l|}{ Academic } \\
\hline & Success criteria & Mean & Success criteria & Mean & Success criteria & Mean \\
\hline \multirow{5}{*}{$\begin{array}{l}\text { Upper Quartile } \\
\left(\mathrm{Q}_{3}\right)_{\text {public }}=5.92 \\
\left(\mathrm{Q}_{3}\right)_{\text {private }}=5.55 \\
\left(\mathrm{Q}_{3}\right)_{\text {academic }}=5.72\end{array}$} & $\begin{array}{l}\text { Effective risk } \\
\text { management }\end{array}$ & 6.23 & Effective risk management & 6.27 & Effective risk management & 6.28 \\
\hline & $\begin{array}{l}\text { Meeting output } \\
\text { specifications }\end{array}$ & 6.00 & $\begin{array}{l}\text { Meeting output } \\
\text { specifications }\end{array}$ & 6.09 & $\begin{array}{l}\text { Satisfying the need for } \\
\text { public facility/service }\end{array}$ & 5.78 \\
\hline & $\begin{array}{l}\text { Satisfying the need for } \\
\text { public facility/service }\end{array}$ & 6.00 & $\begin{array}{l}\text { Reliable and quality service } \\
\text { operations }\end{array}$ & 5.82 & $\begin{array}{l}\text { Reliable and quality service } \\
\text { operations }\end{array}$ & 5.78 \\
\hline & $\begin{array}{l}\text { Adherence to time } \\
\text { schedule }\end{array}$ & 5.92 & $\begin{array}{l}\text { Adherence to time } \\
\text { schedule }\end{array}$ & 5.55 & $\begin{array}{l}\text { Meeting output } \\
\text { specifications }\end{array}$ & 5.72 \\
\hline & & & & & Profitability & 5.72 \\
\hline \multirow{5}{*}{$\begin{array}{l}\text { Lower Quartile } \\
\left(\mathrm{Q}_{1}\right)_{\text {public }}=5.08 \\
\left(\mathrm{Q}_{1}\right)_{\text {private }}=5.00 \\
\left(\mathrm{Q}_{1}\right)_{\text {academic }}=4.94\end{array}$} & $\begin{array}{l}\text { Effective technology } \\
\text { transfer and innovation }\end{array}$ & 5.08 & $\begin{array}{l}\text { Environmental } \\
\text { performance }\end{array}$ & 5.00 & $\begin{array}{l}\text { Effective technology } \\
\text { transfer and innovation }\end{array}$ & 4.94 \\
\hline & $\begin{array}{l}\text { Local economic } \\
\text { development }\end{array}$ & 5.08 & $\begin{array}{l}\text { Effective technology } \\
\text { transfer and innovation }\end{array}$ & 5.00 & $\begin{array}{l}\text { Local economic } \\
\text { development }\end{array}$ & 4.83 \\
\hline & $\begin{array}{l}\text { Reduced project life } \\
\text { cycle cost }\end{array}$ & 5.00 & $\begin{array}{l}\text { Satisfying the need for } \\
\text { project }\end{array}$ & 4.91 & $\begin{array}{l}\text { Reduced public and } \\
\text { political protests }\end{array}$ & 4.61 \\
\hline & $\begin{array}{l}\text { Reduced public and } \\
\text { political protests }\end{array}$ & 5.00 & $\begin{array}{l}\text { Reduced public and } \\
\text { political protests }\end{array}$ & 4.45 & $\begin{array}{l}\text { Reduced project life cycle } \\
\text { cost }\end{array}$ & 4.50 \\
\hline & $\begin{array}{l}\text { Environmental } \\
\text { performance }\end{array}$ & 4.77 & & & & \\
\hline
\end{tabular}

Note: Quartiles cut off values are calculated using the Quartile function in MS Excel.

(A. P. C. Chan, Lam, D. W. M. Chan, \& Cheung, 2008). Misallocation and incomplete transfer of risks in PPPs often end up increasing the total project cost and could also result in improper abrogation of contracts (Ameyaw \& Chan, 2015b). It is therefore very essential for risks to be appropriately identified, shared and transferred completely to the best party so that an effective risk management would be achieved (Roumboutsos \& Anagnostopoulos, 2008). Ideally, political, economic and social risks which obviously go beyond the capability of the private investor have to be retained by the public partner (Ke et al., 2010).

Apart from, "effective risk management", "meeting output specifications" also appeared in the upper quartile subsets of the three stakeholder groups. It is ranked 
second, fourth and second by the public, academic and private sectors respectively (see Table 5). Output based specification is commonly adopted in PPP projects compared to input specifications. The public sector often acts as the client and plays the leading role by specifying the output requirements of which the private sector must satisfy (Lam \& Javed, 2015). Hence, there is a mutual obligation which both parties need to fulfil. This may have contributed to the high rankings of this criterion by the public and private sectors. Although the researchers were quite sceptical on the criterion as a component of their top three success criteria, the mean value (5.72) scored from the researchers still demonstrates its importance in assessing PPP project success. As explained by Osei-Kyei et al. (2017), clear and unambiguous output specifications have to be provided by public sector to enable the private investor or property developer employ adequate measures in order to meet the expected output specifications.

"Satisfying the need for public facility/service", "adherence to time" and "reliable and quality service operations" fall within the upper quartile subsets of only two sectors; the public and academic, public and private, private and academic respectively. Satisfying the need for public facility/service is ranked second and third by the academic and public sectors respectively, whereas the private sector ranked it very low (i.e. $14^{\text {th }}$ ). Furthermore, adherence to time is ranked the same (i.e. fourth) by the public and private sector whereas the academic sector positioned it sixth. This suggests that the key actors in PPP projects put more emphasis on time performance than the researchers. This is not surprising because time is a traditional success measure of construction projects in general; it is mostly considered by projects clients and contractors (Cox, Issa, \& Ahrens, 2003; Bryde \& Robinson, 2005). Importantly, project parties can achieve time performance by avoiding delays during construction. Furthermore, the public sector should ensure that all project permits and approvals are secured on time. The private investor should also ensure that innovative and advanced techniques are adopted in order to expedite the construction process. Reliable and quality service operation is ranked third by the private and academic sectors whereas the public sector ranked it fifth. This finding reveals the private sector's desire to provide efficient and quality services in PPP arrangements, which is a well-known character of the private sector (Osei-Kyei et al., 2014). This therefore implies that the private sector should continue to employ a proper maintenance schedule and competent staff during the operation of PPP projects. This would ensure a more reliable and quality service operation of the public facility. The researchers also believe that the definition of project success has gone beyond the traditional way of measuring success, which are mostly determined based on the satisfaction of project clients and contractors (Khosravi \& Afshari, 2011). However, user satisfaction is also very relevant; therefore a reliable and uninterrupted service delivery/operation would definitely increase the satisfaction level of users/ general public. Although the public sector ranks this success criterion fifth, it has a mean value of 5.77 which is considered as very important in the public sector's ranking. Very often, the public sector is expected to ensure that the end users are fully satisfied with the PPP arrangements. Certainly, the provision of reliable and quality service is a major concern to end users more than any other factor (Meng et al., 2011). This therefore contributes to the high score of this criterion by the public sector.

In the lower quartile section, "effective technology transfer and innovation" and "reduced public and political protests" are the only criteria which fall within each stakeholder group's subset. Effective technology transfer and innovation is ranked $11^{\text {th }}, 13^{\text {th }}$ and $12^{\text {th }}$ by the public, private and academic sectors respectively. Though this criterion is ranked low by the three sectors among the 15 set of success criteria, its mean values (i.e. 5.08 (public), 5.00 (private) and 4.94 (academic)) exceed 4.50 and it is therefore considered important. Notwithstanding, technology transfer and innovation is often not regarded as a key performance objective in PPP project implementation in the developed countries compared to developing countries where the PPP market is dominated by foreign investors (Li et al., 2005a; Dulaimi, Alhashemi, Ling, \& Kumaraswamy, 2010). Therefore, given that more experts from the developed countries participated in this study (approx. $81 \%)$, this may have contributed to the low ranking of this criterion among the 15 set of success criteria. This is however acknowledged as one of the key limitations of the study. Also, reduced public and political protest is ranked very low by each stakeholder group (i.e. $14^{\text {th }}$ (public), $15^{\text {th }}$ (private) and $14^{\text {th }}$ (academic)), however its mean values are closer or above 4.5 , which is considered important. Basically, public and political protests in PPP arrangements are uncommon in the developed countries compared to developing countries (Osei-Kyei \& Chan, 2015b; Amadi, Carrillo, \& Tuuli, 2014). Similarly, the high participation of experts from the developed countries may have contributed to the low ranking of this criterion among the set of success criteria. It is possible that this PPP project success criterion would have been ranked higher if more experts from the developing countries had participated in the study.

The success criteria, "local economic development", "reduced project lifecycle cost" and "environmental performance" are in the lower quartile subsets of only two sectors. Local economic development and reduced project lifecycle cost fall in the lower quartile subsets of the public and academic sectors, whereas environmental performance is within the subsets of the public and private sectors. Although, these success criteria are ranked lower by each sector, their mean values are higher than 4.5 hence they are considered as important. Nonetheless, the low rankings of these criteria demonstrate the level of emphasis each stakeholder group puts on these criteria among the set of 15 PPP project success criteria. 


\subsection{Statistical difference(s) on rankings of PPP project success criteria among the public, private and academic sectors}

Given the diverse roles played by the public, private and academic sectors in PPP project implementation, it was important to statistically examine if there is/are any significance difference/s in the rankings of the set of 15 success criteria for PPP projects among the three independent groups. In this regard, the Kruskal-Wallis test was performed at a significance test value of 0.05 . Table 7 shows the results from the statistical test performed with Kruskal-Wallis on the set of criteria.

From the Kruskal-Wallis test results, only one success criterion (satisfying the need for public facility/service) is statistically significant because it has a p-value below the significant test value of 0.05 (Table 7). On the other hand, the remaining 14 success criteria have their p-values ranging from 0.12 to 0.97 , which are greater than 0.05 hence they are not statistically significant. This implies that all but 'satisfying the need for public facility/service' did not receive significantly different views on their rankings from the three stakeholder groups.
Importantly, results from the Kruskal Wallis test only specified the success criterion which is statistically significant among the three groups of respondents but did not indicate where the significant difference (s) occur between specific groups. In this regard, a post hoc test using Mann Whitney $\mathrm{U}$ statistic is performed to further investigate between which two specific groups lie the significant differences. However, to check for inflation of Type 1 error which is often associated with performing several Mann Whitney $U$ tests, the alpha $(\alpha)$ value was recalculated using the Bonferroni procedure. Table 8 shows the summary of results from the Mann Whitney $U$ test at significance test value of 0.0167 .

The post hoc test results show that the significant differences lie between the private and academic respondents and between the public and private respondents. On the other hand, the significant differences observed do not transpire between the public and academic sectors because their p-value (0.294) exceeds 0.0167 .

Referring to the rankings of the three groups of stakeholders (Table 5), these test results are not surprising. Satisfying the need for public facility/service is ranked $14^{\text {th }}$

Table 7. Results of Kruskal Wallis test on the rankings of success criteria for PPP projects among the public, private and academic sectors

\begin{tabular}{|l|c|c|c|c|c|}
\hline \multicolumn{1}{|c|}{ Success criteria } & $\begin{array}{c}\text { Public sector } \\
\text { Mean rank }\end{array}$ & $\begin{array}{c}\text { Private sector } \\
\text { Mean rank }\end{array}$ & $\begin{array}{c}\text { Academic } \\
\text { Mean rank }\end{array}$ & Chi-Square & p-value \\
\hline Adherence to time & 24.54 & 19.36 & 20.61 & 1.39 & 0.50 \\
\hline Reduced litigations and disputes & 21.85 & 18.91 & 22.83 & 0.85 & 0.66 \\
\hline Effective risk management & 21.31 & 21.27 & 21.78 & 0.02 & 0.99 \\
\hline Reduced public and political protests & 23.65 & 19.27 & 21.31 & 0.93 & 0.63 \\
\hline Reduced project life cycle cost & 21.96 & 26.95 & 17.83 & 4.20 & 0.12 \\
\hline Effective technology transfer and innovation & 22.19 & 21.23 & 21.17 & 0.07 & 0.97 \\
\hline Adherence to budget & 22.62 & 22.45 & 20.11 & 0.47 & 0.79 \\
\hline Meeting output specifications & 22.50 & 23.86 & 19.33 & 1.22 & 0.54 \\
\hline Local economic development & 22.27 & 23.18 & 19.92 & 0.65 & 0.72 \\
\hline Profitability & 22.58 & 16.59 & 23.72 & 2.92 & 0.23 \\
\hline Reliable and quality service operation & 21.23 & 22.14 & 21.31 & 0.05 & 0.97 \\
\hline Satisfying the need for public facility/service & 26.85 & 12.64 & 23.06 & 9.66 & $0.01^{\star}$ \\
\hline Environmental performance & 17.69 & 20.27 & 25.00 & 3.23 & 0.20 \\
\hline Long term relationship and partnership & 24.81 & 19.18 & 20.53 & 1.78 & 0.41 \\
\hline Reduced public administrative cost & 23.19 & 20.23 & 21.06 & 0.49 & 0.78 \\
\hline
\end{tabular}

${ }^{*}$ significance at $5 \%(0.05)$

Table 8. Results of Mann Whitney U test on the rankings of success criteria between specific groups of stakeholders

\begin{tabular}{|l|l|c|c|c|c|}
\hline \multicolumn{1}{|c|}{ Success criteria } & \multicolumn{1}{|c|}{ Sectors } & Mean rank & U statistic & Z & p value (two tailed) \\
\hline \multirow{2}{*}{$\begin{array}{l}\text { Satisfying the need } \\
\text { for public facility/ } \\
\text { service }\end{array}$} & Academic & 14.67 & 93 & -1.049 & 0.294 \\
\cline { 2 - 6 } & Public & 17.85 & & & $0.013^{\star}$ \\
\cline { 2 - 6 } & Private & 10.27 & 47 & -2.48 & \\
\cline { 2 - 6 } & Academic & 17.89 & & & $0.005^{\star}$ \\
\cline { 2 - 6 } & Public & 16 & 26 & & -2.802 \\
\cline { 2 - 6 } & Private & 8.36 & & & \\
\hline
\end{tabular}

*significance test value of 0.0167 
by the private sector whereas the researchers (academic) ranked it second. Similarly, the public sector ranked it third whereas the private sector positioned it $14^{\text {th }}$. The findings therefore suggest that the public and academic sectors strongly opine that 'satisfying the need for public facility/service' is indeed a key success criterion among the 15 set of success criteria for PPP projects, whilst the private sector thinks otherwise. Fundamentally before the inception of PPP projects, the public sector establishes the reasons why a public facility/service is required through pre-feasibility studies (Dulaimi et al., 2010). In this regard, if the implemented PPP project fulfils the need for the public facility/service, the PPP project is considered to have achieved one of the key success criteria of PPP projects from the public sector's perspective. The strong agreement observed between the researchers and the public sector is quite obvious because mostly, the academic sector works closely with the public departments particularly at the planning and preparation stages of PPP projects to investigate and provide feasibility report on the key areas where a public facility is essential (Yuan et al., 2009). Therefore, this may have influenced the researchers' high ranking for this criterion. Importantly, for this criterion to be achieved the public sector with the assistance of the academic should conduct a detailed business case or pre-feasibility studies for the proposed project. Further, competent transaction advisors should be engaged by the public sector and ensure detailed technical, financial and environmental assessments of the proposed project. This will enable the public sector to reliably assess whether the need for the project has been satisfied after the project is completed.

On the other hand, the private sector has a very limited role to play at the planning and preparation stages of PPP projects. Importantly, the private sector plays very little role when a government is devising a national infrastructure plan which elaborates into details why, where and when a public facility/service is needed. Therefore this may have contributed to the low ranking of this success criterion by the private sector.

\section{Implications for PPP practice}

The outputs of this study offer several implications for PPP practice to the public sector and private investors including property and real estate developers interested in PPPs. Specifically, they inform practitioners of the strategic management measures that need to be adopted in order to meet the expectations of each stakeholder when implementing PPP projects. The results indicate that effective risk management and meeting output specifications are the most critical criteria considered by each stakeholder particularly the public and private sectors. As mentioned by Osei-Kyei et al. (2017), prior to the implementation of PPP projects the public client and private developer/investor should identify any possible risk associated with the proposed project and ensure that these risks are allocated to the best party. In addition, parties should avoid incomplete transfer and mistreatment of risks as these will not contribute to the achievement of this criterion. Further, the public sector should provide comprehensive output specifications to make it easier for the private developer/ investor to meet the expected output standards. Also, it is essential that the public sector should avoid setting rigid output requirements; ideally, a more flexible output specification would be beneficial to allow innovation and easy adherence.

The results also indicate that the public and academic sectors are likely to judge the success of PPP projects based on the satisfaction of the need for public facility/ service. This suggests that private investors/developers should employ adequate measures to meet the core needs of procuring a public facility/service through the PPP approach. Essentially, in situations where the need for a public facility seems ambiguous, the private developer should seek clarification from the public authority as well as other external stakeholders. Further, it is essential that the contracting authorities should engage the academic professionals to conduct a thorough business case or prefeasibility studies for the proposed PPP project. This will enable them to establish the essential needs for procuring the public facility through PPP approach.

The results also show that reliable and quality service operation is considered very critical by the private sector compared to the other stakeholders particularly the public sector. This is not surprising because efficiency and quality service operation is a key feature of the private sector. Therefore, it is recommended that private investors/developers employ proper maintenance measures and competent staff in order to maintain that characteristic of the private sector. Further, the public sector also has a role to play by continuously monitoring the performance of the project and also conducting user satisfaction surveys.

\section{Limitation and future research}

The major limitation of this study is the non-participation of users/general public. As mentioned by Rwelamila, Fewings, and Henjewele (2014), the general public should not be marginalized from the definition of "public" in PPP arrangements. This suggests that there is the need to redefine "public" in PPP procurement; therefore it is recommended that the general public should be included in decision makings. However, considering that this study aimed to solicit opinions by means of an international survey, it was impractical to identify and include the general public in an international email/web-survey based research (Zhang, 2004).

This intrinsic limitation can be minimized, if future research is conducted within a specific country or region. It would be practicable to identify and incorporate the general public (i.e. trade unions, civil society groups and non-governmental organizations) who follow very closely PPP developments. 
The second major limitation is the relatively low responses obtained from the academic, public and private sectors. This however affects the generalizability of the survey results (Osei-Kyei \& Chan, 2017). However, the fact that majority of respondents from each stakeholder group have more than six years of research and/or industrial experience in PPP indicates the authenticity of the survey responses (Osei-Kyei \& Chan, 2017). Therefore, the findings are still useful for future reference.

\section{Conclusions}

This paper has explored the perceptual differences on the criteria for determining PPP projects success through an international questionnaire survey targeted on PPP experts from the public, private and academic sectors. Preliminary tests using the Kendall's concordance analysis demonstrate a good association and consistency on the rankings given by experts within each group of stakeholder. This rendered the survey responses adequate and valid for further analysis. The mean score analysis shows that the set of 15 success criteria are considered important by each stakeholder group because their mean values exceeded 4.50. Furthermore, the upper quartile groupings (i.e. $25 \%$ highest values) show that two success criteria fall within the upper quartile subset of each stakeholder group; these include effective risk management and meeting output specifications. Similarly, in the lower quartile groupings (i.e. $25 \%$ lowest values), effective technology transfer and innovation and reduced public and political protests are found in the lower quartile subsets of the three stakeholders. A further analysis using non-parametric tests (i.e. Kruskall-Wallis and Mann Whitney U statistic) indicate that "satisfying the need for public facility/service" is the only success criterion which receives significant difference on its importance among the three groups of respondents. However, the significant differences occur between the public and private sectors and between the academic and private sectors. Explanation for such significant test results is that in PPP project arrangements, the public clients are responsible for determining why, when and where public facilities/services are essential or needed through pre-feasibility studies. Therefore, it is possible they would judge the success of PPP projects based on the fulfilment of the need to procure public facilities/services through PPP. Similarly, because the academic sector works closely with the contracting authorities/public departments particularly during pre-feasibility studies; they may also share the views of the public sector. On the other hand, the private sector has a very limited role to play at the planning and preparatory stages of PPP projects. Hence, they put less emphasis on satisfying the need for public facility/service compared to other PPP project success criteria.

The findings of this study provide significant insights into implementing successful PPP projects which are useful to property and real estate investors interested in PPP arrangements. Importantly, they inform them of the strategic measures that are needed to be adopted in order to meet the expectations of each stakeholder when implementing PPP projects. This will enhance effective cooperation and relationships among stakeholders during the delivery of PPP projects. Also, the results are useful for academics because they complement the existing but limited empirical studies and discussion on the success criteria for PPP projects.

\section{Acknowledgement}

This paper forms part of a $\mathrm{PhD}$ research project entitled "A best practice framework for PPP implementation for infrastructure development in Ghana" from which other papers have been produced with different objective/scope but sharing the same background and methodology. The research project described is fully supported by the Hong Kong PhD Fellowship Scheme from the Research Grants Council (RGC) of the Hong Kong Special Administrative Region and The Hong Kong Polytechnic University, Hong Kong. Authors wish to express their sincere gratitude to all industry practitioners and researchers who participated in this research study.

\section{References}

Akintoye, A., Hardcastle, C., Beck, M., Chinyio, E., \& Asenova, D. (2003). Achieving best value in private finance initiative project procurement. Construction Management and Economics, 21(5), 461-470.

https://doi.org/10.1080/0144619032000087285

Amadi, C., Carrillo, P., \& Tuuli, M. (2014). Stakeholder management in public private partnership projects in Nigeria: towards a research agenda. In A. B. Raiden \& E. AboagyeNimo (Eds.), Proceedings of the $30^{\text {th }}$ Annual ARCOM Conference (pp. 423-432), 1-3 September 2014, Portsmouth, UK: Association of Researchers in Construction Management.

Ameyaw, E. E., \& Chan, A. P. (2015a). Risk ranking and analysis in PPP water supply infrastructure projects: an international survey of industry experts. Facilities, 33(7/8), 428-453. https://doi.org/10.1108/F-12-2013-0091

Ameyaw, E. E., \& Chan, A. P. (2015b). Risk allocation in publicprivate partnership water supply projects in Ghana. Construction Management and Economics, 33(3), 187-208. https://doi.org/10.1080/01446193.2015.1031148

Atkinson, R. (1999). Project management: cost, time and quality, two best guesses and a phenomenon, its time to accept other success criteria. International Journal of Project Management, 17(6), 337-342.

https://doi.org/10.1016/S0263-7863(98)00069-6

Bryde, D. J., \& Robinson, L. (2005). Client versus contractor perspectives on project success criteria. International Journal of Project Management, 23(8), 622-629.

https://doi.org/10.1016/j.ijproman.2005.05.003

Chan, A. P. C., \& Chan, A. P. L. (2004). Key performance indicators for measuring construction success. Benchmarking: An International Journal, 11(2), 203-221.

Chan, A. P. C., Lam, P. T. I., Chan, D. W. M., \& Cheung, E. (2008). Risk-sharing mechanism for PPP Projects - the case study of the Sydney Cross City Tunnel. Surveying and Built Environment, 19(1), 67-80. 
Chan, A. P. C., Lam, P. T., Chan, D. W., Cheung, E., \& Ke, Y. (2010a). Critical success factors for PPPs in infrastructure developments: Chinese perspective. Journal of Construction Engineering and Management, 136(5), 484-494. https://doi.org/10.1061/(ASCE)CO.1943-7862.0000152

Chan, A. P. C., Scott, D., \& Lam, E. W. (2002). Framework of success criteria for design/build projects. Journal of Management in Engineering, 18(3), 120-128. https://doi.org/10.1061/(ASCE)0742-597X(2002)18:3(120)

Chan, A. P. C., Yeung, J. F., Calvin, C. P., Wang, S. Q., \& Ke, Y. (2011). Empirical study of risk assessment and allocation of public-private partnership projects in China. Journal of Management in Engineering, 27(3), 136-148. https://doi.org/10.1061/(ASCE)ME.1943-5479.0000049

Cheung, S. O., Tam, C. M., Ndekugri, I., \& Harris, F. C. (2000). Factors affecting clients' project dispute resolution satisfaction in Hong Kong. Construction Management and Economics, 18(3), 281-294. https://doi.org/10.1080/014461900370654

Cox, R. F., Issa, R. R., \& Ahrens, D. (2003). Management's perception of key performance indicators for construction. Journal of Construction Engineering and Management, 129(2), 142-151. https://doi.org/10.1061/(ASCE)0733-9364(2003)129:2(142)

Cserháti, G., \& Szabó, L. (2014). The relationship between success criteria and success factors in organisational event projects. International Journal of Project Management, 32(4), 613624. https://doi.org/10.1016/j.ijproman.2013.08.008

Davis, K. (2014). Different stakeholder groups and their perceptions of project success. International Journal of Project Management, 32(2), 189-201. https://doi.org/10.1016/j.ijproman.2013.02.006

Davis, K. (2016). A method to measure success dimensions relating to individual stakeholder groups. International Journal of Project Management, 34(3), 480-493. https://doi.org/10.1016/j.ijproman.2015.12.009

Dixon, T., Pottinger, G., \& Jordan, A. (2005). Lessons from the private finance initiative in the UK: benefits, problems and critical success factors. Journal of Property Investment and Finance, 23(5), 412-423. https://doi.org/10.1108/14635780510616016

Dulaimi, M. F., Alhashemi, M., Ling, F. Y. Y., \& Kumaraswamy, M. (2010). The execution of public-private partnership projects in the UAE. Construction Management and Economics, 28(4), 393-402. https://doi.org/10.1080/01446191003702492

Elattar, S. M. S. (2009). Towards developing an improved methodology for evaluating performance and achieving success in construction projects. Scientific Research and Essays, 4(6), 549-554.

Frodell, M., Josephson, P. E., \& Lindahl, G. (2008). Swedish construction clients' views on project success and measuring performance. Journal of Engineering, Design and Technology, 6(1), 21-32. https://doi.org/10.1108/17260530810863316

Garland, R. (1991). The mid-point on a rating scale: is it desirable. Marketing Bulletin, 2(1), 66-70.

Ismail, S., \& Azzahra H. F. (2014). Rationales for public private partnership (PPP) implementation in Malaysia. Journal of Financial Management of Property and Construction, 19(3), 188-201. https://doi.org/10.1108/JFMPC-04-2014-0006

Ke, Y., Wang, S., Chan, A. P., \& Lam, P. T. (2010). Preferred risk allocation in China's public-private partnership (PPP) projects. International Journal of Project Management, 28(5), 482492. https://doi.org/10.1016/j.ijproman.2009.08.007

Khosravi, S., \& Afshari, H. (2011). A success measurement model for construction projects. Proceedings of the International Conference on Financial Management and Economics (pp. 186-190). IPERD, Vol. 11. Singapore: IACSIT Press.
Lai, I. K. W., \& Lam, F. K. S. (2010). Perception of various performance criteria by stakeholders in the construction sector in Hong Kong. Construction Management and Economics, 28(4), 377-391. https://doi.org/10.1080/01446190903521515

Lam, P., \& Javed, A. (2015). Comparative study on the use of output specifications for Australian and U.K. PPP/PFI projects. Journal of Performance of Constructed Facilities, 29(2), 04014061. https://doi.org/10.1061/(ASCE)CF.1943-5509.0000554

Li, B., Akintoye, A., Edwards, P. J., \& Hardcastle, C. (2005a). Critical success factors for PPP/PFI projects in the UK construction industry. Construction Management and Economics, 23(5), 459-471. https://doi.org/10.1080/01446190500041537

Li, B., Akintoye, A., Edwards, P., \& Hardcastle, C. (2005b). Perceptions of positive and negative factors influencing the attractiveness of PPP/PFI procurement for construction projects in the UK. Engineering Construction and Architectural Management, 12(2), 125-148.

https://doi.org/10.1108/09699980510584485

Lim, C. S., \& Mohamed, M. Z. (1999). Criteria of project success: an exploratory re- examination. International Journal of Project Management, 17, 243-248.

https://doi.org/10.1016/S0263-7863(98)00040-4

Liu, J., Love, P., Davis, P., Smith, J., \& Regan, M. (2015). Conceptual framework for the performance measurement of public-private partnerships. Journal of Infrastructure Systems, 21(1), 04014023. https://doi.org/10.1061/(ASCE)IS.1943-555X.0000210

Liyanage, C., \& Villalba-Romero, F. (2015). Measuring success of PPP transport projects: a cross-case analysis of toll roads. Transport Reviews, 35(2), 140-161.

https://doi.org/10.1080/01441647.2014.994583

Meng, X., Zhao, Q., \& Shen, Q. (2011). Critical success factors for transfer-operate-transfer urban water supply projects in China. Journal of Management in Engineering, 27(4), 243-251. https://doi.org/10.1061/(ASCE)ME.1943-5479.0000058

Mladenovic, G., Vajdic, N., Wundsch, B., \& Temeljotov-Salaj, A. (2013). Use of key performance indicators for PPP transport projects to meet stakeholders' performance objectives. Built Environment Project and Asset Management, 3(2), 228-249. https://doi.org/10.1108/BEPAM-05-2012-0026

Osei-Kyei, R., Dansoh, A., \& Ofori-Kuragu, J. K. (2014). Reasons for adopting public-private partnership (PPP) for construction projects in Ghana. International Journal of Construction Management, 14(4), 227-238.

https://doi.org/10.1080/15623599.2014.967925

Osei-Kyei, R., \& Chan, A. P. C. (2015a). Review of studies on the critical success factors for public-private partnership (PPP) projects from 1990 to 2013. International Journal of Project Management, 33(6), 1335-1346.

https://doi.org/10.1016/j.ijproman.2015.02.008

Osei-Kyei, R., \& Chan, A. P. C. (2015b). Developing transport infrastructure in Sub-Saharan Africa through public-private partnerships: policy practice and implications. Transport Reviews, 36(2), 170-186.

https://doi.org/10.1080/01441647.2015.1077288

Osei-Kyei, R., \& Chan, A. P. C. (2017). Perceptions of stakeholders on the critical success factors for operational management of public-private partnership projects. Facilities, 35(1/2), 2138. https://doi.org/10.1108/F-10-2015-0072

Osei-Kyei, R., Chan, A. P. C., Javed, A. A., \& Ameyaw, E. E. (2017). Critical success criteria for public-private partnership projects: international experts' opinion. International Journal of Strategic Property Management, 21(1), 87-100. https://doi.org/10.3846/1648715X.2016.1246388 
Roumboutsos, A., \& Anagnostopoulos, K. P. (2008). Public-private partnership projects in Greece: risk ranking and preferred risk allocation. Construction Management and Economics, 26(7), 751-763. https://doi.org/10.1080/01446190802140086

Rwelamila, P. D., Fewings, P., \& Henjewele, C. (2014). Addressing the missing link in PPP projects: what constitutes the public?. Journal of Management in Engineering, 31(5), 04014085. https://doi.org/10.1061/(ASCE)ME.1943-5479.0000330

Sachs, T., Tiong, R. L. K., \& Wang, S. Q. (2007). Analysis of political risks and opportunities in public private partnerships (PPP) in China and selected Asian countries - survey results. Chinese Management Studies, 1(2), 126-148. https://doi.org/10.1108/17506140710758026

Salman, A. F., Skibniewski, M. J., \& Basha, I. (2007). BOT viability model for large-scale infrastructure projects. Journal of Construction Engineering and Management, 133(1), 50-63. https://doi.org/10.1061/(ASCE)0733-9364(2007)133:1(50)

Spector, P. E. (1994). Using self-report questionnaires in OB research: a comment on the use of a controversial method. Journal of Organizational Behaviour, 15(5), 385-392. https://doi.org/10.1002/job.4030150503

Tiong, R. L. (1996). CSFs in competitive tendering and negotiation model for BOT projects. Journal of Construction Engineering and Management, 122(3), 205-211. https://doi.org/10.1061/(ASCE)0733-9364(1996)122:3(205)

Toor, S. R., \& Ogunlana, S. O. (2010). Beyond the "iron triangle": stakeholder perception of key performance indicators (KPIs) for large-scale public sector development projects. International Journal of Project Management, 28(3), 228-236. https://doi.org/10.1016/j.ijproman.2009.05.005

Turner, R. J., Huemann, M., Anbari, F. T., \& Bredillet, C. N. (2010). Perspectives on projects. Oxon: Routledge.

Wang, X., \& Huang, J. (2006). The relationships between key stakeholders' project performance and project success: perceptions of Chinese construction supervising engineers. International Journal of Project Management, 24(3), 253-260. https://doi.org/10.1016/j.ijproman.2005.11.006
Xu, Y., Chan, A. P. C., \& Yeung, J. F. (2010). Developing a fuzzy risk allocation model for PPP projects in China. Journal of Construction Engineering and Management, 136(8). https://doi.org/10.1061/(ASCE)CO.1943-7862.0000189

Yuan, J., Skibniewski, M. J., Li, Q., \& Zheng, L. (2010). Performance objectives selection model in public-private partnership projects based on the perspective of stakeholders. Journal of Management in Engineering, 26(2), 89-104. https://doi.org/10.1061/(ASCE)ME.1943-5479.0000011

Yuan, J., Zeng, A. Y., Skibniewski, M. J., \& Li, Q. (2009). Selection of performance objectives and key performance indicators in public private partnerships projects to achieve value for money. Construction Management and Economics, 27(3), 253-270. https://doi.org/10.1080/01446190902748705

Zhang, X. (2006a). Public clients' best value perspectives of public private partnerships in infrastructure development. Journal of Construction Engineering and Management, 132(2), 107-114. tps://doi.org/10.1061/(ASCE)0733-9364(2006)132:2(107)

Zhang, X. (2006b). Factor analysis of public clients' best-value objective in public-privately partnered infrastructure projects. Journal of Construction Engineering and Management, 132(9), 956-965. https://doi.org/10.1061/(ASCE)0733-9364(2006)132:9(956)

Zhang, X. Q. (2004). Concessionaire selection: methods and criteria. Journal of Construction Engineering and Management, 130(2), 235-244. https://doi.org/10.1061/(ASCE)0733-9364(2004)130:2(235)

Zhang, X. Q. (2005). Critical success factors for public-private partnerships in infrastructure development. Journal of Construction Engineering and Management, 131(1), 3-14. https://doi.org/10.1061/(ASCE)0733-9364(2005)131:1(3)

Zou, W., Kumaraswamy, M., Chung, J., \& Wong, J. (2014). Identifying the critical success factors for relationship management in PPP projects. International Journal of Project Management, 32(2), 265-274.

https://doi.org/10.1016/j.ijproman.2013.05.004 